\title{
In Vitro Studies on the Developing Embryos of Pinus resinosa
}

\author{
by S. N. BANERJEE and N. W. RADFORTH
}

Received January 27, 1969

\begin{abstract}
Whole embryos of Pinus resinosa excised at various stages of development and cultivated in vitro showed different degrees of potential for growth and differentiation. The influence of physico-chemical environment was maximum during the early stage of development. The suspensor cells could be induced to form budding embryos, or their growth could be arrested. The growth of the suspensor or its lack in vitro was a function of physiological response. Segments of embryos cultivated in vitro showed gradients in potentiality for differentiation in relation to their positions in the embryo and also within themselves in relation to their basal and apical ends. Alternative developmental sequences were observed during regeneration in the segments. The experiments also showed that polyembryony was due to constitutional potentialities in the young embryonic tissue and thus all the cells of an embryonic group could be considered as "embryo initials" under appropriate environmental conditions.
\end{abstract}

It will be agreed that the interaction between the genetic constitution in the dependent embryo and its environment of surrounding parental tissue determines the embryonic differentiation. The inhibition of the development of a hybrid embryo is, generally, accountable to the unsuitability of the environment to the new genotype $^{1)}$. In Sugar Pine hybrids, this inhibitory factor is overcome by dissecting the embryos from the surrounding gametophytic tissue and transferring them to an artificial medium ${ }^{2)}$.

During the embryogeny of Pinus, the development of some of the proembryonal cells is determined at the 16-cell stage. The suspensor cells originate from the second tier of cells just above the embryo initials and normally do not divide again, while the embryo initials divide and give rise to diverse cell types ${ }^{3)}$. This phenomenon of specificity or origin suggests predetermination of differentiation probably connected with differential distribution of cellular contents. This raises the questions about the site at which the differential controls are located and the stage of development at which the differentiation of a cell is determined.

* The investigation was completed at the Dept. of Biology, McMaster University, Hamilton, Ontario, Canada.

** The Ontario Cancer Treatment and Research Foundation, c/o Henderson General Hospital, Hamilon, Ont.; Canada.

*** Chairman, Dept. of Biology, University of New Brunswick, Fredericton, N. B., Canada.

The authors are grateful to the Ontario Research Foundation which offered financial support in connection with this investigation. They gatefully acknowledge the technical assistance of Mr. K. A. Ashdown, Mrs. Maya Banerjee and Mr. J. A. Wilfong. 
Besides these general questions, the students of Pinus embryogeny are further confronted with the phenomenon of polyembryony. The explanation which had received most attention was proposed by Buchholz ${ }^{4}$. It is claimed by Buchholz that the budding form of ontogeny (cleavage polyembryony) in the Pine, which provides for the asexual initiation of four embryos by each zygote, is the more primitive type in living gymnosperms. This explanation was contradicted by Thomson ${ }^{5)}$ and Radforth et $a l^{6)}$.

Spurr ${ }^{7)}$ has furnished information on the histogenesis and organization in the embryo of Pinus strobus. The in vivo studies on the older embryos demonstrate the methods of development of tissue systems but do not include information on the mechanisms controlling ontogeny.

Previous works of the present authors on Ginkgo biloba have established the occurrence of specific changes in the pool of free amino acids in the gametophyte during different stages of embryo development ${ }^{8)}$. Further investigations on the same material revealed a corresponding variation in gibberellin-like and cytokinin-like substances in the gametophytic tissue ${ }^{9,10)}$. From the works cited above, it seemed possible that the biochemical changes seen in the immediate environment of the differentiating embryo may, in fact, be a manifestation of the variation in the potentiality of the embryonic cells for growth and differentiation. The results of the radiobiological studies on the embryo-gametophyte complex of Pinus resinosa also suggested the possibility of a change in the potentiality of embryonic cells for growth and differentiation ${ }^{11}$. In the present work the authors attempt to show that embryonic cells contain varying degrees of potentiality for growth and differentiation at different ontogenetic phases.

\section{Materials and Methods}

Cones of Pinus resinosa were collected locally during the months of July to September. They were bisected longitudinally to facilitate procurement of the seeds which, on removal, were immersed for 15 minutes in $5 \%$ calcium hypochlorite solution and then rinsed in distilled water ${ }^{12}$. From each seed the integument and nucellus were removed to expose the female gametophyte and brown remnants of spore wall. Dissection of the gametophyte was performed as prescribed by Buchhol $z^{3)}$, in an aseptic inoculating chamber and by using a dissecting microscope. The embryos finally removed were washed for 30 seconds in $70 \%$ alcohol and then treated in $1 \%$ sodium hypochlorite solution for 1 minute. They were rinsed in sterilized distilled water, transferred to solid medium and kept in the dark at $27^{\circ}$ under aseptic conditions.

The stages of development in the embryos were easily segregated for identification into four groups according to the degree of development. These stages, for convenience, were designated as I, II, III and IV. The characteristics of each developmental stage has already been published ${ }^{11)}$. As it was difficult to isolate the fertilized egg (Stage I) without causing injury, the present studies involved embryos in stages II to IV.

For each experiment 25 embryos were cultivated. For the study of excised segments, embryos at stage IV were selected. Each embryo was divided transversely into seven pieces at specified positions, and the segments so procured were categorized as shoot apex, hypocotyl, root apex (with a few layers of columnar cells), sub-root apex, suspensorial segment (with 2-3 layers of radicle cells) and suspensorial 
region. As the shoot apex region grew into plantlets easily in preliminary investigations, this segment was not used in the present work. The nutrient medium consisted of a simple inorganic medium ${ }^{12)}$ supplemented by extract from Ginkgo gametophyte. To prepare it, $0.43 \mathrm{~g}$ potassium chloride; $0.11 \mathrm{~g}$ calcium sulphate; $0.1 \mathrm{~g}$ magnesium sulphate and $0.11 \mathrm{~g}$ magnesium phosphate were dissolved in a litre of distilled water.

For the supplement of gametophyte extract, Ginkgo ovules were collected during the month of July. The gametophytes were removed from the integument and $10 \mathrm{~g}$ of tissues were crushed with sterile silica and extracted with $50 \mathrm{ml}$ of hot water at room temperature for two hours, then filtered. To the filtrate $50 \mathrm{ml}$ of the inorganic solution and $2 \mathrm{~g}$ sucrose were added. This made $100 \mathrm{ml}$ of medium the $\mathrm{pH}$ of which was adjusted to 5.5 by adding phosphate buffer. For solidification, $1.5 \mathrm{~g}$ bacto agar was added per $100 \mathrm{ml}$ medium. The medium was dispensed in $20 \mathrm{ml}$ test tubes, $8 \mathrm{ml}$ to a tube each of which was plugged with cotton. These tubes were then autoclaved for 30 minutes at 15 pounds pressure.

Controls for these experiments consisted of intact ovules containing embryos and grown in complete White's medium as described previously ${ }^{11)}$. All the cultures were harvested at the end of 5 weeks. Material for anatomical study was fixed in formalin-propionic acid-alcohol, dehydrated in tertiary butyl alcohol series and embedded in tissue mat. Sections were cut to $10 \mu$ in thickness and stained in Heidenhain's haematoxylin, safranin-fast green, borax carmine-fast green and borax carmine-aniline blue ${ }^{13)}$.

\section{Results}

Experiments with whole embryos:

Stage II explants

At the onset of differentiation each of the controls when acquired from the in vivo source consisted of a small spheroidal mass of cells arranged terminally on a thin filamentous attachment (Fig. 1). The terminal cells were all alike and the terminal mass lacked visible differentiation. These embryos when placed in vitro, gave rise to various patterns of growth and form.

In three cases, the embryos grew three dimensionally into a rounded mass. Within each complex, the cells at the distal end were larger than those at the proximal end (Fig. 2). Als J cell division was confined to and localized at the distal end.

In sixteen cases there was profuse proliferation of the suspensorial cells and the embryo was cylindrical. Cells at the distal end were indistinguishable from those at the proximal end of the cylinders. At the junction of the suspensor and the main embryonic mass a single cell was observed which was distinct from the rest (Fig. 3 , top).

In six cases the cultured embryos were organized into elongated cylindrical masses (Figs. 4, 5). The cells at distal and proximal ends were all of the same shape, but those at one end differed in arrangement from those at the other. Cells of the distal end were equidimensional and scattered whereas at the proximal end they were equidimensional but arranged in rows. Differentiation was arrested at this stage. Examination of embryos growing in vivo (Fig. 6) showed more growth than those cultivated in vitro. 


\section{Stage III explants}

Embryos of the controls showed initiation of primary root (radicle) tissue. The root initials consisted of 3 or 4 cells dividing at an oblique plane (Fig. 7, top).

The embryos cultured in vitro produced both root and shoot apices (Fig. 8). The root cap was well established with columnar cells present (Fig. 9). The shoot apex was rounded and with elevated shoulders, presumably cotyledonary primordia. A pith-like core of cells was initiated in the hypocotyl. These cells were bigger than the others of the ground tissue and were stained lighter. Below this region procambial strands occurred. Cells of these strands were dividing vertically, and were narrow and more heavily stained than the surrounding cells.

In seven of the cultured embryos budding had occurred at different places in the suspensor cell well below the rosette cells (Fig. 10). These secondary embryos lacked a filamentous attachment although some of them had acquired a characteristic oblong shape. No mark of cellular specialization was discernible in them.

When compared with embryos developed in vivo but older than those of the controls, those grown in vitro showed evidence for a slower rate of growth. Those developed in vivo were bigger, the shoot apex had assumed a more conical shape and the cotyledons were well developed (Fig. 11).

\section{Stage IV explants}

Embryos of the control (Fig. 12) showed advanced development at the apical and basal ends; slightly elevated shoulders at the shoot apex and a defined rounded epicotyl.

From this stage embryos cultured in vitro developed to maturity with a conical shoot apex and well developed cotyledons. The differentiation of procambium and pith was complete and they responded to differential staining (Figs. 13, 14, 15). The procambium strands in the hypocotyl-shoot axis were continuous with those of cotyledons.

Secondary embryos were developed from suspensorial sources during this period. They had acquired and now displayed a variety of growth patterns. In five cases they had elongated and differentiation had been initiated. In three of the five cases root initials had formed and a root cap with cells arranged in columnar fashion was noticed but the shape of the secondary embryos had remained spheroidal (Fig. 16).

A summary of the results is conveyed in Table 1 and a synopsis of the characteristic development for each phase is presented in Table 2.

\section{Experiments with excused segments of embryos (Stage IV)}

Results of in vitro experiments entailed consideration of six regions of the embryos. The hypocotyl was one of these. Examination, following growth, showed that cell division occurred more frequently at the apical (cut) end, close to shoot apex, than at the basal end (Figs. 17, 22, 23). The epidermis was unaltered and in some cases cell expansion occurred in the cortical cells beneath it. Additional cortical cells sometimes arose to the extent of 2 to 3 layers at the apical end (Fig. 26). The basal cells had elongated and contained granular inclusions, a normal feature in the gametophytic cells. These segments did not proliferate to form callus but instead maintained a regular growth pattern already in existence.

The next region for consideration was the sub-hypocotyl. This segment also showed difference in developmental pattern at the basal (towards root apex) ends (Figs. 18, 24, 25). At the apical end the centrally located cells (pith?) produced a 
Table 1. Summary of results on development of whole embryos cultivated in vitro.

\begin{tabular}{|c|c|c|c|c|c|c|}
\hline $\begin{array}{l}\text { Stage of } \\
\text { develop- } \\
\text { ment }\end{array}$ & $\begin{array}{l}\text { No. normal } \\
\text { embryos } \\
\text { developed/ } \\
\text { Total culti- } \\
\text { vated }\end{array}$ & $\begin{array}{l}\text { No. abnormal } \\
\text { embryos/Total } \\
\text { cultivated }\end{array}$ & $\begin{array}{c}\text { Type of } \\
\text { abnormality }\end{array}$ & $\begin{array}{l}\text { No. embryos } \\
\text { producing } \\
\text { secondary } \\
\text { embryos }\end{array}$ & $\begin{array}{c}\text { Stage in } \\
\text { secondary } \\
\text { embryo }\end{array}$ & $\begin{array}{l}\text { Shape of } \\
\text { secondary } \\
\text { embryo }\end{array}$ \\
\hline II & $6 / 25$ & $19 / 25$ & $\begin{array}{l}\text { Proliferation } \\
\text { of suspensor, } \\
\text { rounded } \\
\text { embryo, un. } \\
\text { differentiated }\end{array}$ & - & - & - \\
\hline III & $14 / 25$ & $11 / 25$ & $\begin{array}{l}\text { Slower rate } \\
\text { of growth, } \\
\text { cotyledons } \\
\text { not developed, } \\
\text { secondary } \\
\text { embryo } \\
\text { formed }\end{array}$ & 7 & II & $\begin{array}{l}\text { No suspen- } \\
\text { sor, } \\
\text { spheroidal } \\
\text { shape un- } \\
\text { differenti- } \\
\text { ated }\end{array}$ \\
\hline IV & $22 / 25$ & $3 / 25$ & $\begin{array}{l}\text { Secondary } \\
\text { embryo } \\
\text { formed }\end{array}$ & $\begin{array}{l}2 \\
+ \\
1\end{array}$ & $\begin{array}{l}\text { II } \\
+ \\
\text { III }\end{array}$ & $\begin{array}{l}\text { Spheroidal, } \\
\text { differenti- } \\
\text { ated }\end{array}$ \\
\hline
\end{tabular}

Table 2. Development of embryos excised at different phases of differentiation (arbitrarily designated) and grown in vitro.

\begin{tabular}{|c|c|c|}
\hline Phase of differentiation & Shape of primary embryo & Differentiation-distinctive features \\
\hline Stage II & Spheroidal & $\begin{array}{l}\text { Proliferation of suspensors ; cell } \\
\text { division localized at distal end; root } \\
\text { initials formed. }\end{array}$ \\
\hline Stage III & Elongated, cylindrical & $\begin{array}{l}\text { Rounded shoot apex delineated; } \\
\text { spheroidal embryos budded from } \\
\text { suspensor, root and shoot apices } \\
\text { differentiated; cotyledonary } \\
\text { primordia, procambium, and pith } \\
\text { formation initiated. }\end{array}$ \\
\hline Stage IV & $\begin{array}{l}\text { Elongated, cylindrical } \\
\text { cotyledons evident }\end{array}$ & $\begin{array}{l}\text { Pith, procambium and cotyledons } \\
\text { well developed. Procambium from } \\
\text { the main axis of embryo coninuous } \\
\text { into cotyledon. Suspensorial embryos } \\
\text { differentiated. }\end{array}$ \\
\hline
\end{tabular}

small compact mass of additional cells in the fashion of pseudomeristem (Fig. 28). The cells at the basal end maintained their pattern of growth except at the cut surface where very small cells were observed. These cells were stained lighter than their neighbours. The cortical cells in this region divided periclinally, which displaced the epidermis outwards. Some of these cells had expanded beyond usual size and had few inclusions (Fig. 27).

The third region under consideration was the root apex. The columnar and the peripheral cells conformed to the original pattern of orientation. Peripheral cells were not derived from the central core. The columnar cells were close-packed. The epidermis was intact and no cell expansion was observed in the cortical cells (Fig. 19, 29). In short, this segment when in vitro retained morphological features characteristic of the in vivo condition.

The fourth region comprised cells below the root apex, the sub-root apex. This segment was constituted of central and peripheral cells which became reoriented in 
vitro. In the controls the central cells (column) were arranged in long vertical files. This orientation was achieved through a predominance of transverse divisions. In the segments grown in vitro, the columnar structure was absent. The new cells formed were small and showed predominance of division by an oblique plane. The peripheral region retained the radial orientation of the cells (Figs. 20, 30).

In one case, the regeneration of a pseudo-root apex occurred. A group of comparatively smaller cells at the apical end (toward root apex) of the segment was found to be arranged on an arc created by cells dividing in a vertical plane (Fig. 36). These cells were distinct from the cells of the peripheral region. Apparently, the core (column) had contributed some cells to the peripheral layer. This form of development contrasted with that in normal histogenesis.

The fifth region was that described as the suspensorial segment which included part of suspensor and 2-3 layers of columnar cells. The old suspensorial cells proliferated little (Fig. 21). The adjacent radicle cells ultimately gave rise to a meristematic region akin to that in a normal root apex. The development of the meristem was assisted by a change in the plane of division of the columnar cells. These cells divided in a vertical instead of in the usual (cf. in vivo) transverse plane (Fig. 31). The associated filamentous structure was limited to a few long cells at the base of the newly formed apex (Fig. 31). Each of these cells was anucleate.

The last region to be considered was represented by the suspensor. When isolated suspensors were cultivated in vitro they underwent enormous proliferation and produced several budded embryos (Fig. 32). The embryogeny was anomalous in that one of the filamentous cells produced a multinucleate structure (Fig. 33). The mechanics of division producing this structure could not be followed. It ultimately gave rise to a spheroidal embryo attached by a short filament presumably derived from the parental suspensorial mass (Fig. 34). In another case the budded embryo had no filamentous attachment (Fig. 35). A summary of the results on the excised segments is given in Table 3.

Table 3. Summary of results on excised segments cultivated in vitro.

\begin{tabular}{l|c|c|c}
\hline \multicolumn{1}{c|}{ Segment } & $\begin{array}{c}\text { No. abnormal } \\
\text { segment/total } \\
\text { cultivated }\end{array}$ & $\begin{array}{c}\text { Characteristics of abnormal } \\
\text { differentiation }\end{array}$ & $\begin{array}{c}\text { Change in cortical } \\
\text { cells }\end{array}$ \\
\hline Hypocotyl & $3 / 25$ & $\begin{array}{l}\text { Difference in cells at two cut } \\
\text { ends, basal cells granular, } \\
\text { slower rate of cell division } \\
\text { Very small cells at basal cut } \\
\text { end, pseudomeristem at apical } \\
\text { cut end }\end{array}$ & Cell expansion \\
$\begin{array}{l}\text { Sub-hypocotyl } \\
\begin{array}{l}\text { Root apex with } \\
\text { few layers of } \\
\text { columnar cells }\end{array}\end{array}$ & $7 / 25$ & $\begin{array}{l}\text { Sub-root apex } \\
\text { Subion }\end{array}$ & \\
$\begin{array}{l}\text { Suspensors with } \\
2-3 \text { layers of } \\
\text { radicle cells } \\
\text { Suspensors }\end{array}$ & $9 / 25$ & $\begin{array}{l}\text { Column absent, pseudapex } \\
\text { formed } \\
\text { Change in the plane of cell } \\
\text { division of columnar cells }\end{array}$ & \\
\hline
\end{tabular}




\section{Discussion}

The first manifested step in embryonic differentiation is the onset of polarity ${ }^{14)}$. The results listed for whole embryos in Table 2 show that for the phase in which differentiation is already initiated, polarity already imposed on the post-zygotic mass as a whole can be reoriented. Suspensorial tissue surmounts whatever inhibitory mechanism prevails for the in vivo condition and reverts in the in vitro environment to the function of production of undifferentiated three dimensional cell masses. Moreover, this function of the suspensorial zone, the basal portion of the axis of polarity for the primary embryo is sustained throughout the ontogenetic history. Finally, retention of the function for proliferation of three dimensional (non-filamentous) masses can be expected to occurr even when the suspensorial explant has been removed experimentally from potential influence of neighbouring non-suspensorial cells of the original embryonic mass. This ability is now known to persist for at least as late as Stage IV. By this time the pattern of differentiation had already oriented itself about the primary axis of polarity.

In all the experiments, extract from Ginkgo gametophytes prepared from collections of July had been used. Steward $e t a l .{ }^{15)}$ had shown that similar extract was $65 \%$ efficient as compared to the coconut milk factor for the growth of free cell suspension from phloem of carrot root. Ginkgo gametophyte extract contains 12 free amino acids, and gibberellin-like and cytokinin-like substances ${ }^{8,9,10)}$. In the present work the same extract facilitated normal ontogeny in the case of differentiation designated within Stage IV but not in Stage II of development. Thus, it was evident that the environmental conditions exerted greater influence on the early ontogeny than on the later stages. Furthermore, embryos cultivated in Stage III produced a maximum number of secondary embryos. This may imply that the potentiality for growth and differentiation in the cells of an embryo reaches a peak at this stage. This can be achieved if the number of de-repressed genes in the embryonic cells is also a maximum at this stage. This contention is quite in agreement with previous studies on Pinus embryos ${ }^{11)}$,

The potentiality of suspensor cells to differentiate in vitro had been observed by earlier workers. Bonga ${ }^{16)}$ and Wood ${ }^{17)}$ observed pitted structure in the suspensor under cultural conditions. The suspensorial embryos in the present work were mostly rounded structures with or without filamentous attachment. The fact that this radial development occurred only under specific nutritional environment supported the contention that the origin of the suspensor was through physiological response and not phylogenetic sequence. This view was contrary to the "primitive spindle" theory advanced by Bower ${ }^{18)}$.

The formation of embryos from the excised suspensors and from the suspensors of intact embryos grown in vitro can be explained as arising through a loss of inhibitory influences in the immediate environment. The suspensor, in vivo, is inhibited to proliferate or differentiate because of its position on the embryo axis and/ or its position on the metabolic gradient of the gametophyte. This means that budding (cleavage) polyembryony is a latent expression in this species. This is enough to cast doubt on the hypothesis that the asexual initiation is a forerunner of simple polyembryony or indeed that there is any phylogenetic significance associated with polyembryony in plants ${ }^{4}$.

The totipotency of free cells cultured from phloem of carrot to give rise to a plant was shown by Steward ${ }^{14)}$. Thus the potentiality to reproduce the whole 
organism by any part should be regarded as an inherent or constitutional feature derived from the original organization of the cell. This view was quite in agreement with the view of Thomson who "preferred to regard cells of an embryonic group as potential embryo initials rather than actual embryo initials "19).

The break with filamentous development and the imposition of three dimensional growth pattern provides evidence against the argument for ontogenetic predetermination in the zygote. Also, where there are departures from in vivo ontogeny in the in vitro results, response is with respect to groups of cells and not with a single initial. Our observations also show that for the interpretation of growth pattern the emphasis, at least tentatively, must be neither on phylogenetic nor on fixed genetic attitudes in protoplasts but on the considerable influence of the physicochemical environment on the development of the organism.

\section{References}

1) Datta, R. M., and Baner jee, S. N., Genetica $31: 385$ (1960).

2) Stone, E.C., and Duffield, J.W., Jour. For. $48: 200$ (1950).

3) Buchholz, J. T., Bot. Gaz. $66: 185$ (1918).

4) - Trans. Ill. Acad. Sci. $23: 117$ (1931).

5) Thomson, R.B., Trans. Roy. Soc. Can. 39 : 143 (1945).

6) Radforth, N.W., and Pegararo, L., ibid. $49: 69$ (1955).

7) Spurr, A. R., Amer. J. Bot. $36: 629$ (1949).

8) Banerjee, S. N., and Radforth, N. W., Ind. Agric. 10: 33 (1966).

9) —, Plant and Cell Physiol. 8:207 (1967).

10) , Bot. Mag. Tokyo $81: 67$ (1968).

11) - ibid. $81: 11$ (1968).

12) Radforth, N. W., Trans. Roy. Soc. Can. $21: 21$ (1936).

13) Johansen, D. A., Plant Microtechnique, McGraw-Hill, N. Y. (1940).

14) Steward, F.C., Amer. J. Bot. 45: 709 (1958).

15) - and Shantz, E.M., Ann. Rev. Pl. Physiol. 10 : 379 (1959).

16) Bonga, J.M., Ph.D. Thesis, McMaster Univ., Canada, (1960).

17) Wood, A.B., M. Sc. Thesis, McMaster Univ., Canada, (1953).

18) Bower, F. O., Proc. Roy. Soc. Edin. 43: 1 (1922).

19) Radforth, N. W., Bot. Gaz. $110: 339$ (1948).

\section{Illustrations}

Fig. 1. Control embryo at Stage II phase. $\times 60$.

Fig. 2. Embryo grown in vitro at Stage II phase-round mass, no suspensor. $\times 110$.

Fig. 3. Stage II phase embryo grown in vitro - central cell different from the rest. $\times 90$.

Fig. 4. Stage II phase embryo grown in vitro-cells at proximal end bigger. $\times 110$.

Fig. 5. Stage II phase embryo grown in vitro-cells at proximal end arranged in rows. $\times 90$.

Fig. 6. Stage II phase embryo in vitro-greater growth. $\times 40$.

Fig. 7. Control embryo at Stage III phase-root initials formed. $\times 110$.

Fig. 8. Stage III phase embryo in vitro-epicotyl rounded, cotyledon primordia formed. $\times 25$.

Fig. 9. Stage III phase embryo in vitro-root apex well developed with columnar cells $\times 400$.

Fig. 10. Stage III phase embryo in vitro, two embryos budded at different places on the suspensor, much below the rosette cells. $\times 75$.

Fig. 11. Stage III phase embryo in vitro-cotyledons well developed, epicotyl conical. $\times 25$.

Fig. 12. Control embryo at Stage IV phase, root and shoot apices well developed. $\times 75$.

Fig. 13. Stage IV phase embryo in vitro, mature embryo. $\times 15$.

Fig. 14. Stage IV phase embryo in vitro, tissue system formed. $\times 20$.

Fig. 15. Stage IV phase embryo in vitro, continuity of procambial strands into cotyledons 
and pith formation. $\times 100$.

Fig. 16. Stage IV phase embryo in vitro, suspensorial embryos showing differentiation of root initials and columnar cells, one embryo spheroidal. $\times 90$.

Fig. 17. Hypocotyl segment in vitro. $\times 15$.

Fig. 18. Sub-hypocotyl segment in vitro. $\times 15$.

Fig. 19. Root apex segment in vitro. $\times 15$.

Fig. 20. Sub-root apex segment in vitro. $\times 15$.

Fig. 21. Suspensorial segment with 2-3 layers of radicle cells in vitro. $\times 15$.

Fig. 22. L.S. of hypocotyl segment at the apical end showing cell division and expanded cells. $\times 750$.

Fig. 23. Basal end of the hypocotyl segment showing granulation in cells. $\times 750$.

Fig. 24. L.S. of sub-hypocotyl segment at the apical end showing normal cells. $\times 250$.

Fig. 25. Basal end of the sub-hypocotyl segment showing smaller cells. $\times 250$.

Fig. 26. Hypocotyl segment showing expansion in cortical cells and granulation. $\times 475$.

Fig. 27. L.S. of sub-hypocotyl segment showing intact epidermis and no expansion in cortical cells. $\times 475$.

Fig. 28. L.S. of sub-hypocotyl segment showing pseudo-meristem formation. $\times 450$.

Fig. 29. L.S. of root apex segment showing normal orientation of cells. $\times 450$.

Fig. 30. L.S. of sub-root apex segment showing absence of columnar structure. $\times 450$.

Fig. 31. L.S. of fig. 21 showing formation of a meristem by the radicle cells. Suspensor cells are limited to few long cells at the base and are anucleate. $\times 475$.

Fig. 32. L.S. of excised suspensor grown in vitro showing budded embryo. $\times 90$.

Fig. 33. L.S. of suspensorial segment showing ontogeny of budding embryo; a filamentous embryo with 4 nuclei. $\times 750$.

Fig. 34. L.S. of a budded suspensorial embryo showing filamentous attachment. $\times 250$.

Fig. 35. L.S. of a suspensorial embryo showing absence of filamentous attachment. $\times 90$.

Fig. 36. L.S. of sub-root apex segment showing regeneration of a pseudo-root apex. $\times 500$. 


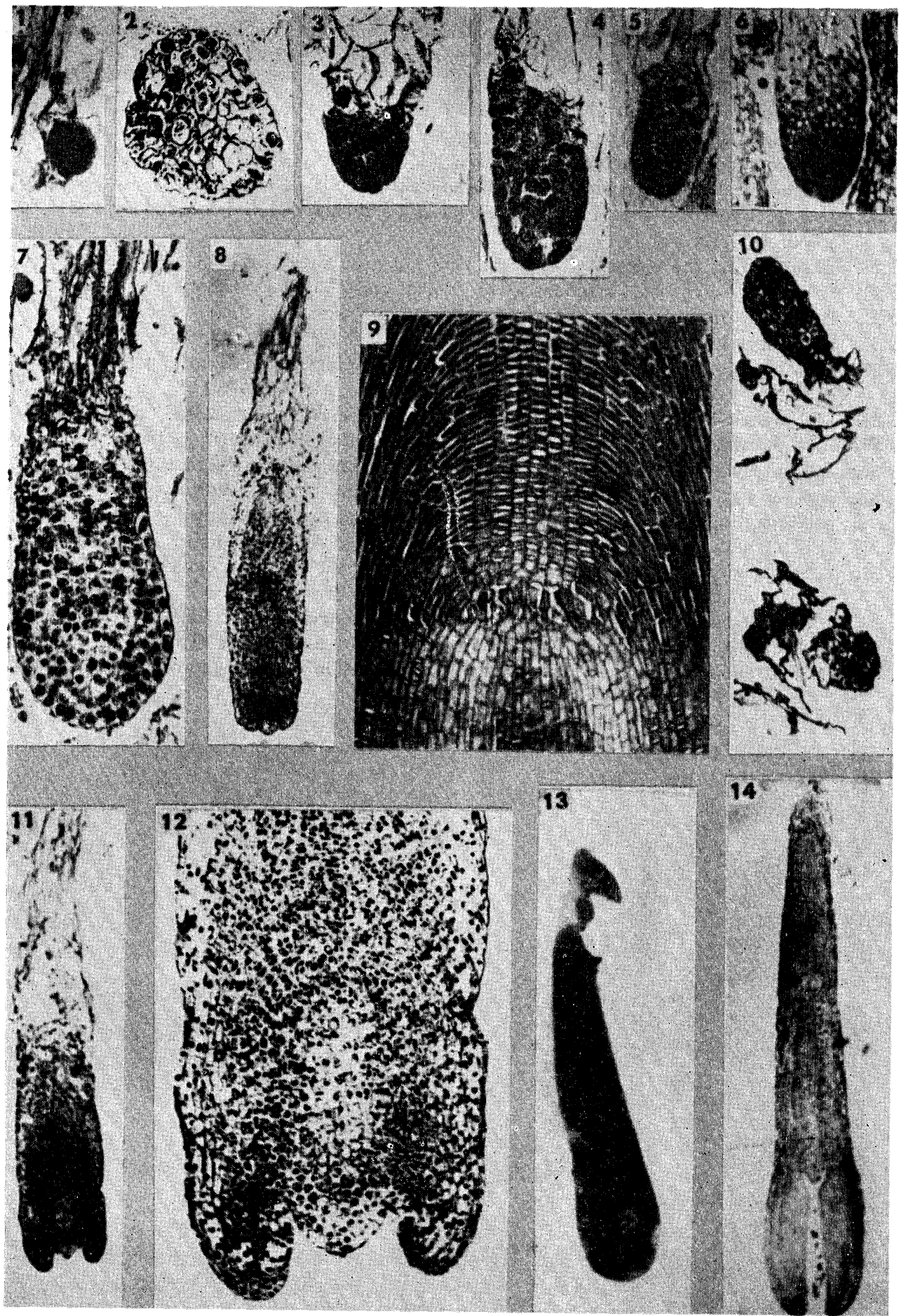




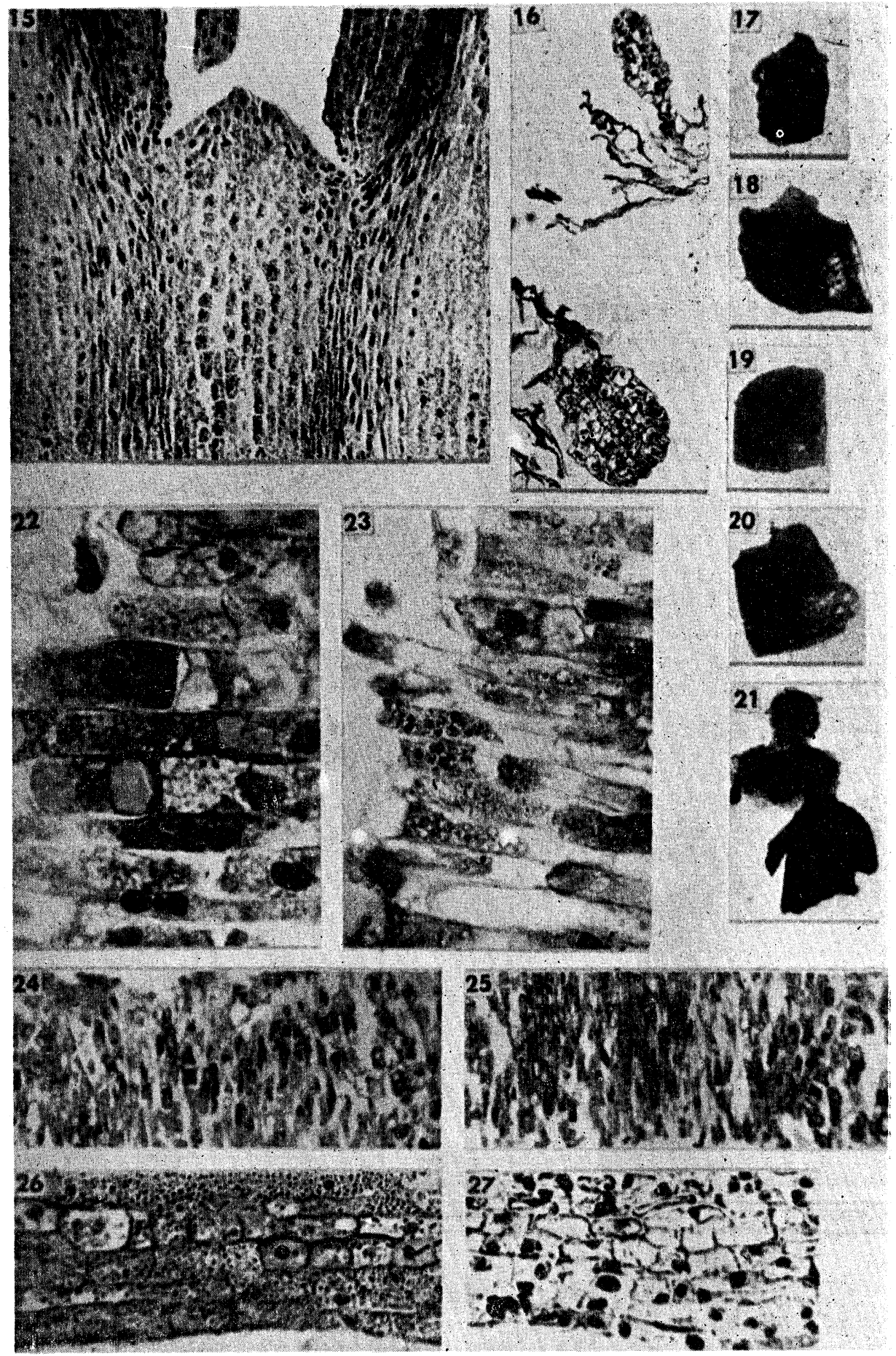



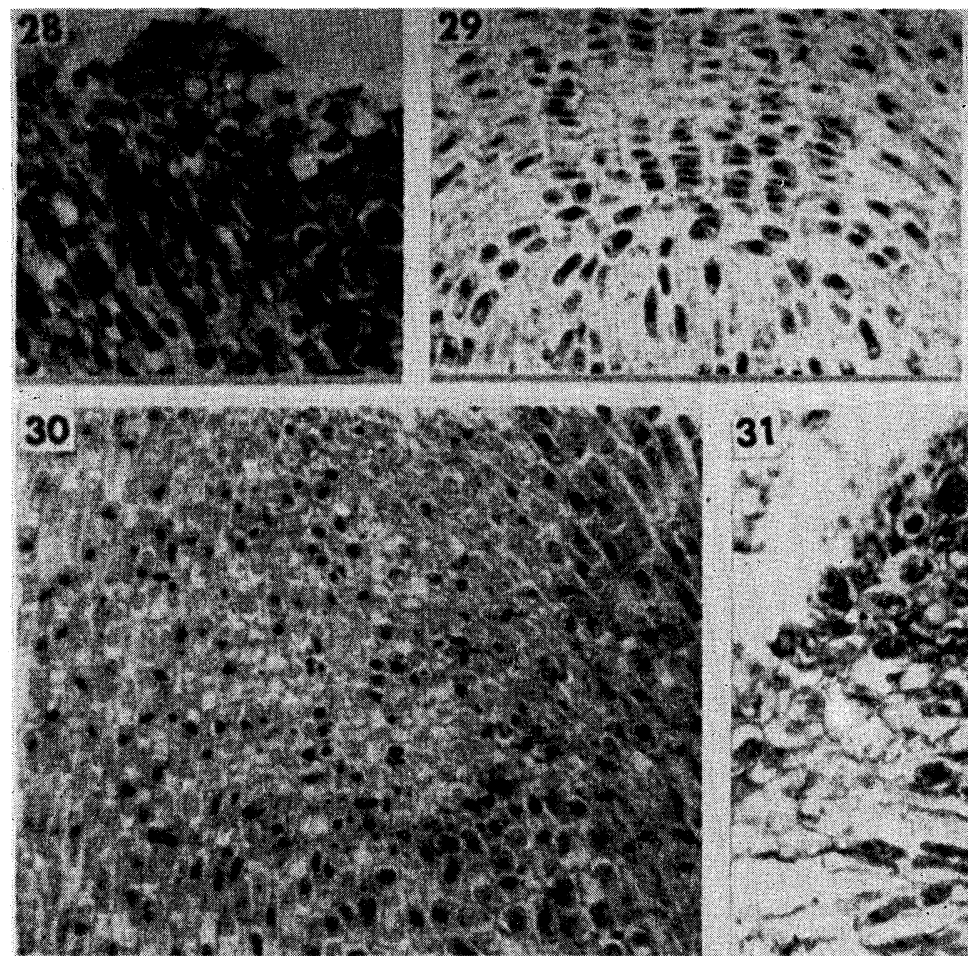

$31: 9$

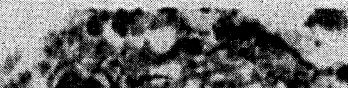

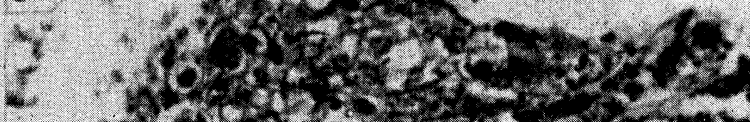

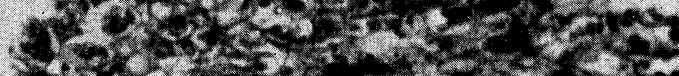

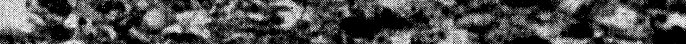

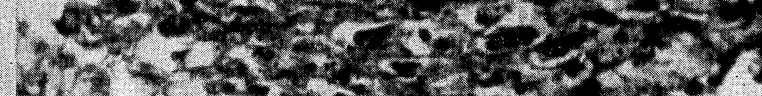

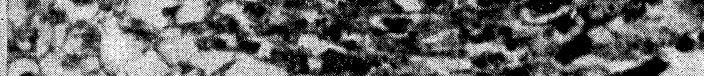

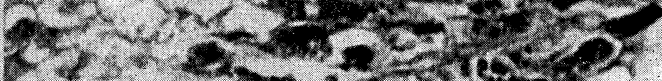

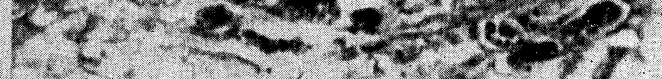

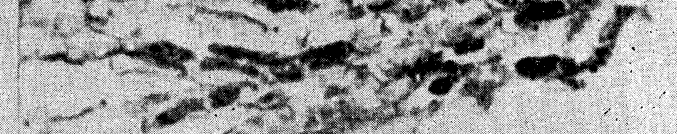
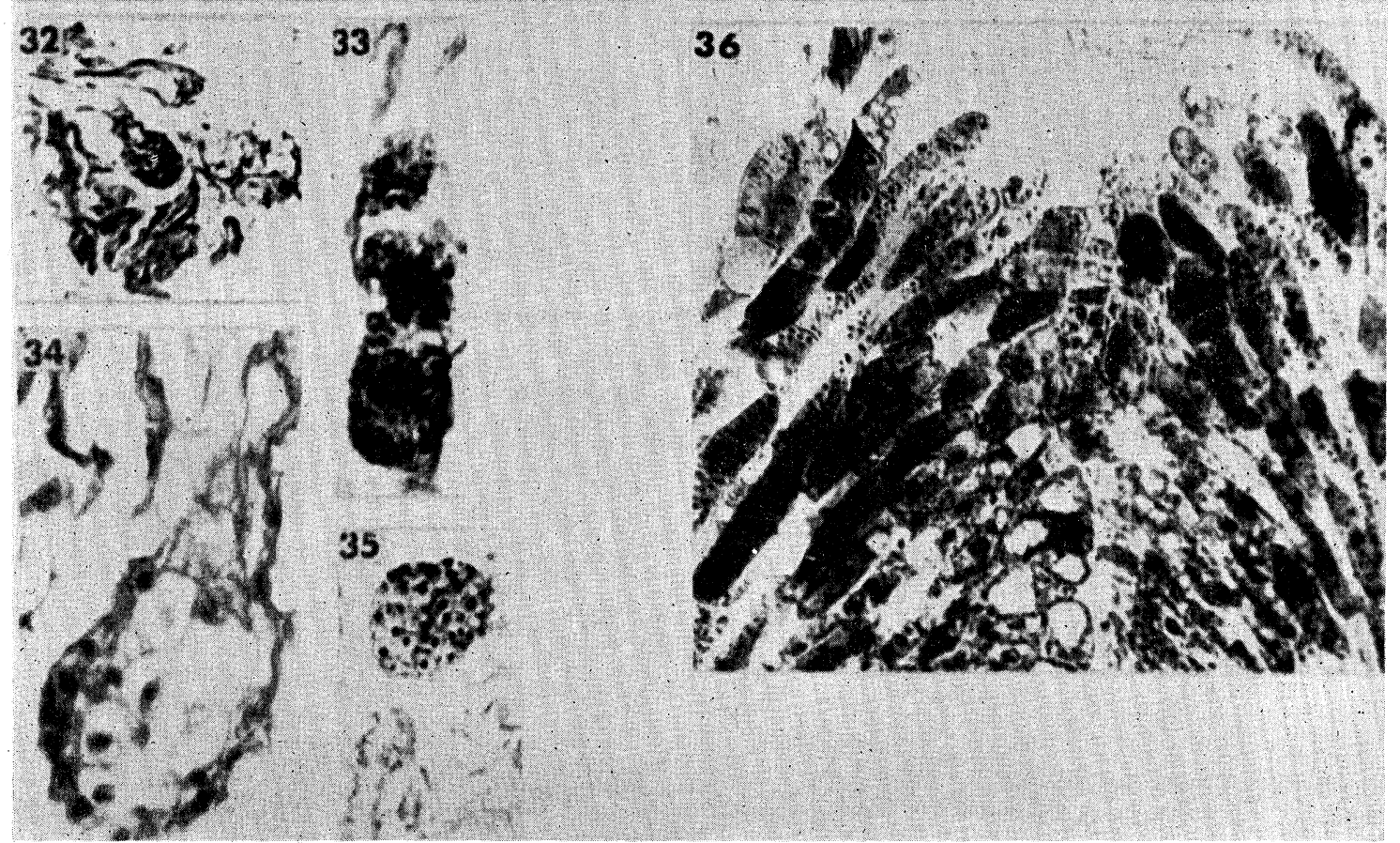